Journal of Community Based Environmental Engineering and Management, 2020, Vol. 4, No. 1: 25-30

\title{
FOOD WASTE CONTROL RECOMMENDATIONS IN INDONESIA BASED ON PUBLIC OPINION RELATED TO THE TARGET SDGS
}

\author{
Indriyani Rachman ${ }^{1,2, *}$, Asyifa Imanda Septiana ${ }^{3}$ \\ 1) Faculty of Environmental Engineering, the University of Kitakyushu, Japan \\ 2) Graduate Program, Pakuan University, Indonesia \\ ${ }^{3)}$ Department of Software Engineering, Universitas Pendidikan Indonesia, Indonesia
}

\begin{abstract}
Food waste has an impact that can harm or disrupt human life. In Indonesia, food waste management has not been done in an integrated manner. This study was conducted to formulate recommendations for the proper handling of food waste for the people of Indonesia. Formulation of foodwaste management was carried out after collecting and processing data from respondents. Data on conditions and public opinion were obtained from 2 groups of respondents, namely the general public and environmental engineering students from several universities. Cluster analysis, AMOS approach and text mining were ulitzed as methods in data processing and analysis. The results showed that public opinion about knowledge of food waste is quite high. These recommendations for handling food waste are through the habits of food producers, the community as consumers, distribution of food before it expires, processing it into animal feed, processing it into an energy source with anaerobic digestion, and processing it into compost with good cooperation between waste collectors, companies composting and farmers using compost.
\end{abstract}

Keywords: foodwaste, public opinion, recommendation actions

\section{Introduction}

Every year, the estimated population of the earth causes food waste of 1.3 billion food waste (Gustavsson et al., 2017). The habit of not eating food is the main cause of this food waste. High organic content in food waste requires fast management. When entering the landfill, the waste will increase methane emissions included in greenhouse gases.

In Indonesia, food waste management has not been done in an integrated manner, especially in relation to the $3 \mathrm{R}$ program. $3 \mathrm{R}$ waste management is waste management which

${ }^{*}$ Corresponding Author:

E-mail: rachmanindriyani@gmail.com

Received: 31 January 2020

Revised: 14 February 2020

Accepted: 13 March 2020 involves community participation so that program sustainability is maintained (Yustiani et al., 2019). Food that has the potential to become junk, can be used for consumption before it expires. This utilization requires a fast and integrated handling process.

This becomes serious, because the accumulation of food waste in landfills has the potential to cause methane gas from anaerobic reactions of food waste which are harmful to the ozone layer causing global warming.

Food waste has an impact that can harm or disrupt human life. This problem has been a global concern for a long time. In 2000, world leaders agreed on 8 specific and measurable global development goals called the Millennium Development Goals (MDGs). In September 2015, more than 150 political leaders met in New York City to adopt the new United Nations 
Sustainable Development Goals (SDGs). There are 17 targets set in the world sustainable development agenda for the next 15 years. In Goal 12 regarding material consumption, there is Goal 12.3 which works for food waste, namely "By 2030, global per capita food waste at the retail and consumer levels and reducing food losses along with production and supply chains, including post-harvest losses".

In addition, food waste is closely related to Target No. 13 on Action Against Climate, namely "Take urgent action to combat climate change and its impacts", and Target \# 2, World Without Hunger, namely "By 2030, end hunger and ensure access by all people, in particular the poor and people in vulnerable situations, including infants, to safe, nutritious and sufficient food all year round ". The problem of global food waste is very important to be solved from the perspective of reducing hunger and improving the environment by reducing carbon emissions and landfill use.

Indonesian people are also expected to cause large amounts of waste. The results showed that food waste from restaurants can reach 2 liters / person/ day (Brigita et al, 2013). At certain times, for example during the fasting month, the resulting waste increases (Muhtarom, 2010). In efforts to handle food waste in Indonesia, especially those based on the $3 R$ concept, the conditions and public opinion need to be known. This study was conducted to formulate recommendations for the proper handling of food waste for the people of Indonesia.

\section{Research Methodology}

\section{Data Collecting}

Data on conditions and public opinion were obtained from 2 groups of respondents, namely the general public and environmental engineering students from several universities.
To the general public respondents, questionnaires were distributed about food waste, including knowledge, awareness and opinions.

From the student respondents, data obtained in the form of writing about food waste which includes background, causes and alternative solutions to problems. The writing was made after student respondents watched a video about the problem of food waste in Indonesia.

\section{Data Processing}

1. Data Processing of Public Respondents

Data processing obtained from general public respondents was processed using the Cluster Analysis method with SPSS tools. Cluster analysis is carried out to group objects based on similar characteristics (Facca et al., 2011). In addition, the AMOS (Analysis of Moment Structure) method is also used for processing data from the public. This approach includes technical cases such as linear models and general factor analysis. In this study, the AMOS approach is used to see the relationship between all the questions in the questionnaire and the profile and SGDs. The software used in this approach is the IBM SPSS AMOS v.22 application.

\section{Data Processing of Student Respondents}

Text mining techniques are used to process data from student respondents based on the writing they make. Text mining is used to extract information from an article (Salloum et al., 2018). This technique uses the principle of indexing and filtering out the most words that appear in an article. This data processing will produce data about the level of respondents' knowledge of food waste.

\section{Result and Discussion}

Questionnaire Results

1. Cluster Analysis 
Test results using Cluster Analysis show that there are 3 groups in the general public, namely:

a. Group 1; is a group that has a high level of education, a higher consumption budget compared to other groups and has high knowledge too but has very bad habits related to food waste. Group 1 is considered not to have high awareness of the environment, including the waste generated.

b. Group 2; is the group that has the lowest level of education when compared to groups 1 and 3, has a medium consumption budget, has lower knowledge than others but has good habits. These good habits can be formed not because of the level of education, but because of the condition of consumption patterns that are not excessive.

c. Group 3; is a group that has a medium level of knowledge, has a lower consumption budget than the other two groups, but has higher knowledge about food waste than the other groups and has good habits in dealing with food waste problems. In this group, it is seen that the level of awareness of the environment is relatively high by not easily disposing of food because it has a low budget.

2. Results of the AMOS Approach

Table 1 Result of Model Testing by AMOS

\begin{tabular}{cccl}
\hline Parameter & $\begin{array}{c}\text { Reference } \\
\text { value }\end{array}$ & $\begin{array}{c}\text { Test } \\
\text { result }\end{array}$ & $\begin{array}{c}\text { Model } \\
\text { Evaluation }\end{array}$ \\
\hline $\begin{array}{c}\text { Chi } \\
\text { Square }\end{array}$ & Nearly 0 & 8.004 & Good \\
\hline Probability & $\geq 0,05$ & 0.993 & Good \\
\hline CMIN/DF & $\leq 2.00$ & 0.670 & Good \\
\hline RMSEA & $\leq 0,08$ & 0.0002 & Good \\
\hline GFI & $\geq 0,90$ & 0.951 & Marginal \\
\hline
\end{tabular}

The values of the test results shown in Table 1 indicate that the model has passed the goodness of fit test.
Through the AMOS Statistics Program it can be analyzed and calculated the results of regression weights between latent variables which are often referred to as loading factor estimates (Hariyadi, 2014). From the results of this regression analysis it can be seen how high the influence of an endogenous variable on the exogenous variable. The effect of age, education, and consumption budget on each questionnaire answer.

Squarred Multiple Correlation analysis shows that all variables contained in the questionnaire are influenced by age, education and consumption budget.

Regression Weight results contain data on the estimated value of the effect of endogenous variables on the exogenous variables contained in the model. Based on the AMOS approach, it was found that the most significant variable influencing the level of respondents' knowledge was the level of education. The level of knowledge will affect habits, but not significantly. This shows that although the respondents have good education, good knowledge, it does not necessarily make good habits in managing food waste.

If $3 \mathrm{R}$ concept is used, then a good habit that must be prioritized is to reduce the potential for waste generation. This can occur among other things if food is not spent, buying too much cooking ingredients, storing food ingredients for too long.

\section{Text Mining Results}

Based on the results of text mining analysis, several opinion factors were obtained in relation to the indicators on SDGs Goal 2 and Goal 13, namely:

1. The role of the government and the community in developing their area of residence by creating a garbage bank organization. This garbage bank can manage waste in the area. And 
the organic waste is turned into fertilizer or makes a garbage power plant.

2. Increased knowledge, awareness and behavior. The public should understand about food waste and its effects.

3. Making local NGOs/ local movements that can accommodate these food ingredients.

\section{Program Recommendation}

Efforts to reduce food waste can be done in restaurants that have high potential as a source of generation. Provision of trays to place fast food is one of the causes of high food waste, especially in canteens that offer food in separate containers. Excessive food collection occurs especially when canteen visitors wait in line to pay for the food they buy. The method without tray is proven to reduce food waste in restaurants by $37 \%$ per cuisine and $54 \%$ per person at UC Santa Barbara, USA. (https://www.news.ucsb.edu, accessed 31 January 2020).

The habits of producers in providing food products can be improved by regular market surveys. This market survey is important to do to determine the amount of food that needs to be produced so that it does not exceed too much market demand. In addition, consumer habits in buying food also need to be improved so as not to buy in excess quantities. Delivery (delivery) system can help improve the purchase in excess quantities.

Improving consumer habits can be done through education and promotion. Because habits are a reflection of the knowledge and experience gained by the community, improvement efforts can be carried out through community advertising, dissemination of success stories, etc. Education about shopping habits can be given from an early age and exemplified by public figures. In addition, public awareness as consumers can also be increased through knowledge and information about the savings that occur when shopping in moderation.

Food waste reduction can also be done by processing food from food that does not meet food industry standards. Food industry raw materials that are still suitable for consumption can be collected in a shelter. The foodstuffs collected are then processed into foods whose expiry rate is faster so that food quality is still good when consumed. In addition, some products from the food industry that do not pass the quality control process also have the potential to continue to be consumed. This condition can be considered if the product is still suitable for consumption and safe for health.

Food collection program has been implemented in Japan as Food Waste Bank "Live Again". Based on research in Japan, food waste generated can reach 20 million tons / year. From this figure, there are around $32 \%$ which are still suitable for consumption. This food bank activity requires contributions from food producers and the government (Sato et al., 2016).

Efforts to handle food waste can also be done by using it as animal feed. This can be done if the food waste is no longer suitable for consumption by humans but can still be eaten by animals. Several types of food waste, whether in the form of meat, vegetables, fruits, and bread have the potential to be good animal feed (Truong et al, 2019).

Food waste that cannot be reduced can be processed into compost with the condition that there is no other content in the waste other than food. In addition, food waste can also be used as an energy source using the most ecofriendly anaerobic digestion process (Paritosh et al., 2017).

Processing food waste into compost requires good cooperation between companies that generate waste, companies processing waste into 
compost, and compost users. This collaboration will overcome the problem that usually occurs in composting production, i.e. not compost produced. If composting is subsidized by the food waste collection and compost industry that is produced is used by groups of farmers who work together, then the problem can be overcome.

\section{Conclusion}

Food waste in Indonesia requires handling in several aspects that involve the community, because the concept that needs to be focused is 3R. The results showed that public opinion about knowledge of food waste is quite high. These recommendations for handling food waste are through the habits of food producers, the community as consumers, distribution of food before it expires, processing it into animal feed, processing it into an energy source with anaerobic digestion, and processing it into compost with good cooperation between waste collectors, companies composting and farmers using compost.

\section{References}

Gustavsson, J., Cederberg, C., Sonesson, U., Van Otterdijk, R., Meybeck, A., 2011. Global Food Losses and Food Waste. Food and Agriculture Organization of the United Nations. Rom. http://www.fao.org/docrep/014/mb060e/m b060e00.pdf

Yustiani, Y.M., Rochaeni, A., Aulia, E. 2019. Konsep Pengelolaan Sampah di Desa Babakan Kabupaten Bandung, EnviroScienteae, Vol. 15, No. 1, pp. 121126

Salloum, S.A., Al-Emran, M., Monem, A.A., Shaalan, K. 2018. Using Text Mining Techniques for Extracting Information from Research Articles, Intelligent Natural Language Processing: Trends and Applications, Studies in Computational
Intelligence 740, pp. 373-397.

Facca, T.M., Allen, S.J. 2011. Using Cluster Analysis to Segment Students Based on Self-Reported Emotionally Intellegent Leadership Behaviors, Journal of Leadership Education, Vo.1. 10, Issue 2, pp. 72-96.

Marini. 2012. Kajian Penggunaan Software AMOS/LISREL berdasarkan Pendekatan TAM, Seminar Nasional Aplikasi Teknologi Informasi (SNATI) 2012.

Hariyadi, H. 2014. Analisa Keterkaitan antara Lingkungan Keselamatan dan Kesehatan terhadap Produktivitas Kerja dengan Metode Structural Equation Modeling (Studi Kasus: PT. Media Karya Sentosa Gresik), Jurnal MATRIK, Vol. XV, No. 1, pp. 55-65.

Brigita, G., Rahadian, B. 2013. Analisa Pengelolaan Sampah Makanan di Kota Bandung, Jurnal Teknik Lingkungan, vol. 19, no. 1, pp. 34-45.

Muhtarom, K. Perilaku Konsumsi Masyarakat Jakarta Timur Sebelum dan Saat Ramadhan, Al-Istishad, Vol. II, No. 2, pp. $55-78$.

https://www.news.ucsb.edu/2009/012718/trayles s-dining-composting-projects-aresustainability-successes-ucsb (diakses 31 Januari 2020).

Sato, M., Nakano, M. 2016. Activity of the Food Bank in Japan and Problems based on the viewpoint of Shokuiku Education, Nihon Shokuiku Gakkai Shi, Vol. 10, No.1, pp. 31-40

Paritosh, K., Kushawa, S.K., Yadav, M., Pareek, N., Chawade, A., Vivekanand, V. 2017. Food Waste to Energy: An Overview of Sustainable Approaches for Food Waste Management and Nutrient Recycling, BioMed Research International, Vol. 
2017, Article 2370927, 19 p.

Truong, L., Morash, D., Liu, Y., King, A. 2019. Food Waste in Animal Feed with a Focus on Use for Boilers, International Journal of Recycling of Organic Waste in Agriculture, Vol. 8, pp. 417-429. 